\title{
An Updated Review on Epidemiology, Pathophysiology, Diagnosis and Treatment aspects of COVID-19 Infection
}

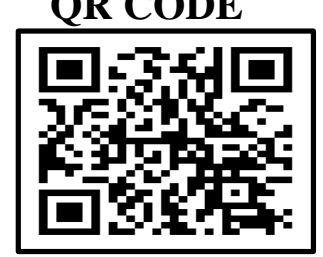

\section{ARGHYA BHATTACHARYA*11, RITABRATA KUNDU², LOKESH CHANDRA MAHATA3, SHIBAM KUNDAGRAMI ${ }^{4}$,} BIKRAM DHARA5'D, DATTATREYA MUKHERJEE6 ${ }^{6}$

In the current era, COVID-19 has become the most familiar term in the whole world. It is caused by the novel coronavirus SARS-CoV-2 which is a mutated congener of SARS COV and MERS COV. As per epidemiological studies, 83959 cases have been recorded only in China with 4637 deaths. More than 215 countries including Korea, Iran, Italy, Germany, Algeria, South Africa, Senegal, Nigeria etc have recorded over nine million deaths due to this pandemic. Diagnosis of COVID-19 can be carried out by several ways like identifying the increased level of lactate dehydrogenase, creatinine kinase, alanine and aspartate dehydrogenase in blood. IgG and IgM antibody detection is a key parameter in detection of SARS CoV-2. The real-time reverse transcriptase-polymerase chain reaction or RT-qPCR test is so far considered the most reliable diagnostic method. Recently, two current approaches get widely used in diagnosis for SARS CoV-2 namely "FELUDA" and "SHERLOCK" offering a cheap and less time taking procedure for the detection of SARS CoV-2. In FELUDA a protein called FnCas9 and a guide RNA (g RNA) helps in recognizing the viral gene which is contained by the sample whereas SHERLOK is associated with Casi2 protein.

KEYWORDS: SARS CoV-2, RT- qPCR, +ssRNA, Resolution Computed Tomography

\section{INTRODUCTION}

The world had to face a novel dreadful disease known as COVID-19 first time in the year of 2020; the so called COVID-19 is caused by a specific viruscoronavirus which is considered as a mutated congener of SARS-COV \& MERS-COV. Corona virus is +ss RNA of 26-32 kb with a 5'cap and 3' tail poly A tail possessing 14 putative open reading frames (ORF) that encode 27 proteins. The virion, however, consists of four types of proteins-S(spike), E(envelop), $\mathrm{M}$ (membrane) and $\mathrm{N}$ (nucleocapsid). Structural morphology shows that RNA genome is held by $\mathrm{N}$ protein whereas $\mathrm{S}, \mathrm{E}$ and $\mathrm{M}$ altogether create viral capsid. ${ }^{1}$ The subfamilies of coronavirus are- alpha, beta, gamma and delta. ${ }^{2}$

Several zoonotic coronaviruses cause severe infection in humans like HCoV 229E, HCoV NL63, HCov HKU1 and $\mathrm{HCoV}-\mathrm{OC} 43 .{ }^{3}$ It is to note that SARS-CoV which originated from bat emerged in Guangdong outbroke with about $10 \%$ case fatality rate (CFR) whereas MERS $\mathrm{CoV}$ originated from dromedary camel (first reported in Saudi Arabia in June 2012 and later in 27 countries) having a CFR of about 34\%.3., The virus closely related to SARS-CoV is RaTG13-2013 that was identified in a bat. On the other hand, the complete genome of severe acute respiratory syndrome coronavirus 2 isolated from Wuhan $\mathrm{Hu}-1$ is available at (https://www.ncbi.nlm) and genetic epidemiology of HCV-19 and submitted data are available from GIASID database (https://www.giasid.org/). The SARS-CoV consists of at least ${ }_{11 O R F s}$ with full length of 29,903 bp., ${ }^{5,6}$ Taking into consideration the severity and rising rates of infection, WHO confirmed COVID 19 as a pandemic on March 11, 2020 and fruitful steps were chalked out including quarantining the contaminated persons and their family members, maintenance of social distancing, closure of academic institutions etc. $^{7}$

In late December 2019, patients were admitted to hospital with an initial diagnosis of pneumonia of an unknown etiology; those patients were epidemiologically linked to a sea food and wet animal market in Wuhan, Hubei province. Dr Jianguo Xu, an academician of the Chinese Academy of Engineering who led a research team, declared at a national conference that the outbreak was caused by a new type coronavirus, tentatively dubbed 2o19new coronavirus $(2019 \mathrm{nCoV})$ by the World Health Organization. ${ }^{8}$

There are predominantly two groups that are at 
elevated risk of developing severe disease - geriatric patients and patients with diabetes mellitus, cardiorespiratory disorders, renal failure, hypertension, pregnancy and chronic liver disease. ${ }^{9}$

Epidemiology and Viral Transmission (Figure 1): Previous reports documented that coronavirus is a zoonotic pathogen which arose from sea food in China and afterwards it spread in humans. As per reported data, 83,959 cases were observed in China along with 4637 deaths ( $2^{\text {nd }}$ May,2020). On the other hand, over 9 million deaths were recorded in more than 215 countries like Korea, Iran, Italy, Germany, South Africa, Nigeria and India. ${ }^{10}$

COVID-19 principally spreads via respiratory droplet transmission from person to person when a person is in close contact with somebody actively sneezing and coughing. Transmission may also occur through fomites used by or used on infected individual such as bed sheets, blankets, kitchen utensils, thermometer and stethoscope. The patients of COVID-19 belong mostly to the age group of $40-70$ years and the incubation period is 5-6 days which can exceed up to 14 days. ${ }^{11}$

Apart from SARS-COV, there are several types of coronaviruses that can infect humans namely HCOV 299E, HCOVNL63, HCOV-OC43, HCOV HKU1 etc. ${ }^{2}$ The gene sequence of $2016-\mathrm{nCoV}$ is 89 percent identical to bat SARS-like coronavirus ZXC21 (bat-SLCoVZXC21, accession no. MG772934.1) and ZC45 (MG772933.1), and 82 percent identical to SARS-CoV Tor2 (JX163927), suggesting that 2019-nCoV belongs to betacoronavirus Lineage B. ${ }^{12}$
Diagnosis (Figure 2): Diagnosis can be carried out by a number of ways. Blood tests show increased levels of lactate dehydrogenase, an elevated neutrophil to lymphocyte ratio though overall WBC count is reduced. Coagulation abnormality is related with increase in prothrombin time and international normalize ratio. ${ }^{14}$ Apart from the serological test that detect IgG and Ig $\mathrm{M}$ antibodies against SARS $\mathrm{CoV}-2$, RT- qPCR also play a crucial role in detecting nucleic acid of SARS CoV-2: the samples are collected from lower respiratory tract aspirate, nose, sputum, nasopharyngeal oropharyngeal swabs. Ultrasound and CT scan are also taken in consideration for diagnosis of COVID-19. These are essential modalities used in the treatment of Cardio respiratory failure in the Intensive Care Unit (ICU). ${ }^{15}$ High Resolution Computational Tomography (HCRT) is an extremely sensitive method of choice even in preliminary stage of the illness. In terms of laboratory tests, a normal or decreased total white blood cell count and a decreased lymphocyte count might be seen in the early stages of the disease. There are elevated levels of liver enzymes, $\mathrm{LDH}$, muscle enzymes, and C-reactive protein. The procalcitonin level is normal. The Ddimer value is elevated in critical patients, blood lymphocytes are consistently lowered, and laboratory alterations of multiorgan imbalance (high amylase, coagulation disorders, etc.) are detected. ${ }^{14}$

A very newly found approach 'FELUDA' is a cheap and less time taking method. FELUDA is an acronym for FnCas9 Editor Limited Uniform Detection Assay and uses CRISPER-CAS technique specific for detection of the genes specific to SARS-COV 2 viruses - In this method, a protein called FnCas9 and a guide RNA

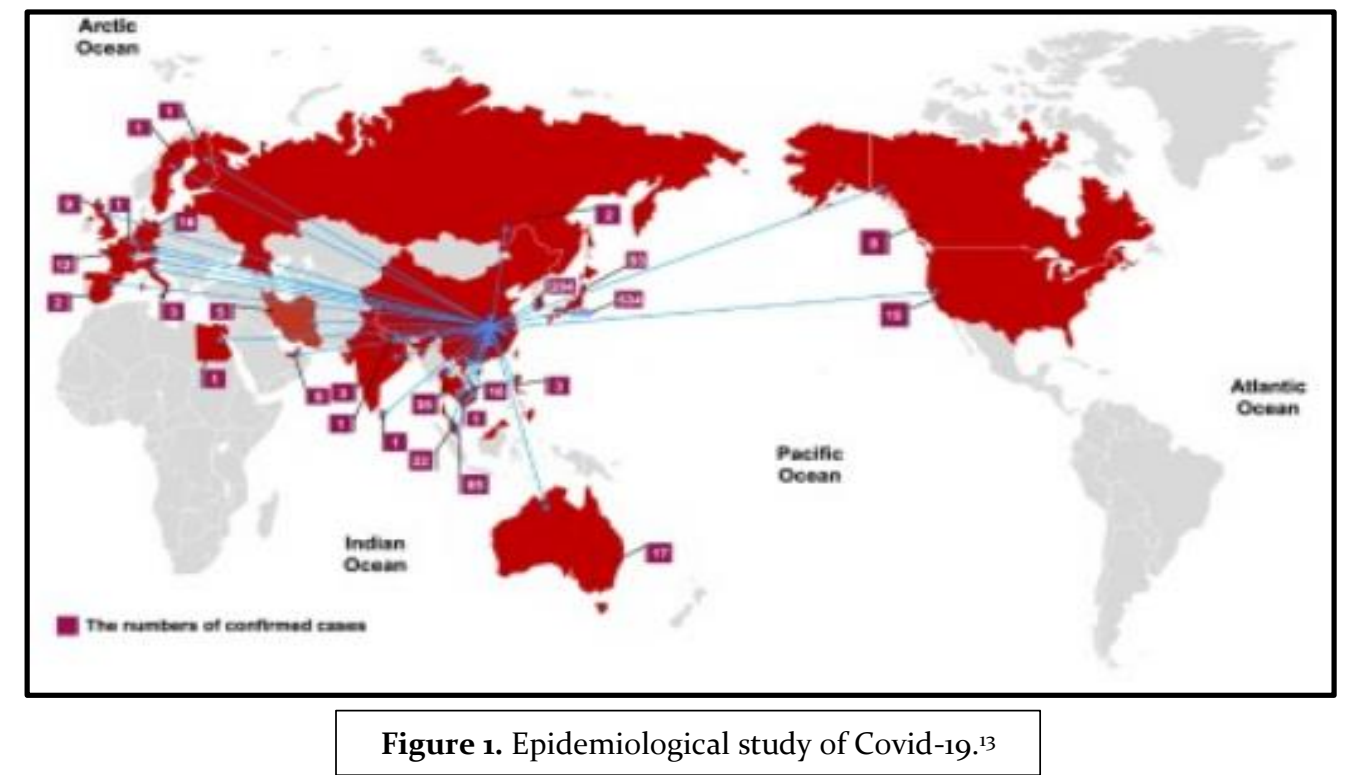

International Healthcare Research Journal 2022;5(11):RV1-RV6. 
(gRNA) which helps in recognizing viral gene are used. If the sample contains gene, this gRNA-FnCas9 complex binds to gene and their bond is visualized by paper strip. This aforementioned method is quite similar to SHERLOCK (Specific High Sensitivity Enzymatic Receptor Unlocking) which is associated with Cas 12 protein in place of Cas 9. Serological tests are used for detecting IgG and IgM antibodies against SERS COV 2 in the sputum, plasma and sometimes whole blood. ${ }^{16}$

Pathophysiology (Figure 3): Corona virus is a +ssRNA (29.9 kb) of size 50-200 nm diameter and characterizes as $\alpha, \beta, \gamma, \delta$. The RNA encodes 27 proteins. The virus, however consists of four types of proteins - E (epidermal), M (membrane), N (nucleocapsid) and S (spike). S protein is further subdivided into $S_{1}$ and $S_{2}$ subunit. $S_{1}$ is responsible for receptor bond and $S_{2}$ is considered as fusion subunit in order to carry out virion attachment and fuse with cell membrane. TMPRSS 2 plays a vital role by cleaving the $\mathrm{S}$ protein from $\mathrm{S}_{1} / \mathrm{S}_{2}$ cleave site. ${ }^{13}$

ACE2 is regarded as functional receptor for SARS $\mathrm{CoV}$-2. Although ACE2 can also be observed in other cells likes GIT, Liver and kidney vascular epithelium in a highly expressive mode. ${ }^{18}$ Newly formed nucleocapsids are enclosed in ER membrane and transported to lumen - Golgi vesicle - cell membrane - extracellular space (by mean of exocytosis). ${ }^{14}$ Immune response is cauterized by release of $\mathrm{C}-\mathrm{X}-\mathrm{C}$ motif chemokine ligand and interferons IFN $\alpha$ and IFN $\beta$ from the virus infected cell. ${ }^{19}$ The invasion of virus inside pulmonary myocytes and endothelial causes edema degeneration and necrotic changes. These changes are primarily connected to activation of pro inflammatory cytokines (IL6, ILıo, TMF $\alpha$ ), granulocyte colony stimulatory factor, monocyte chemo attractant protein 1, macrophage inflammatory protein $1 \alpha$, programmed cell death marker (PD1), T cell immunoglobulins and mucin domain $(\mathrm{Tm}-3)$ that are found to be increased. ${ }^{14,20}$ Patients infected with COVID 19 suffer from fever, malaise, dry cough, shortness of breath, loss of taste or smell, red or irritated eye etc. ${ }^{9}$

Treatment: Remdesivir is considered as an adantageous drug of choice in treatment of COVID19. It blocks DNA polymerase. Apart from that protease inhibitors like Lopinavir and Ritonavir can also play a crucial role in the cure of corona patients. Chloroquine which is generally treated as an antiprotozoal drug prevents the glycosylation of the ACE-2 receptor, besides it terminates the penetration of SARS CoV-2 by increasing the $\mathrm{pH}$ of epidermal layer. ${ }^{22}$

In addition, azithromycin is used in treatment of virus associated with bacterial infection. ${ }^{23}$

Vaccines for COVID-19 include ZycovD (launched by Zydus Cadilla), Covaxin (launched by Bharat Biotech), Covishield (AstraZeneca in cooperation with Oxford university). ${ }^{24}$

Prophylactic anticoagulation is performed by

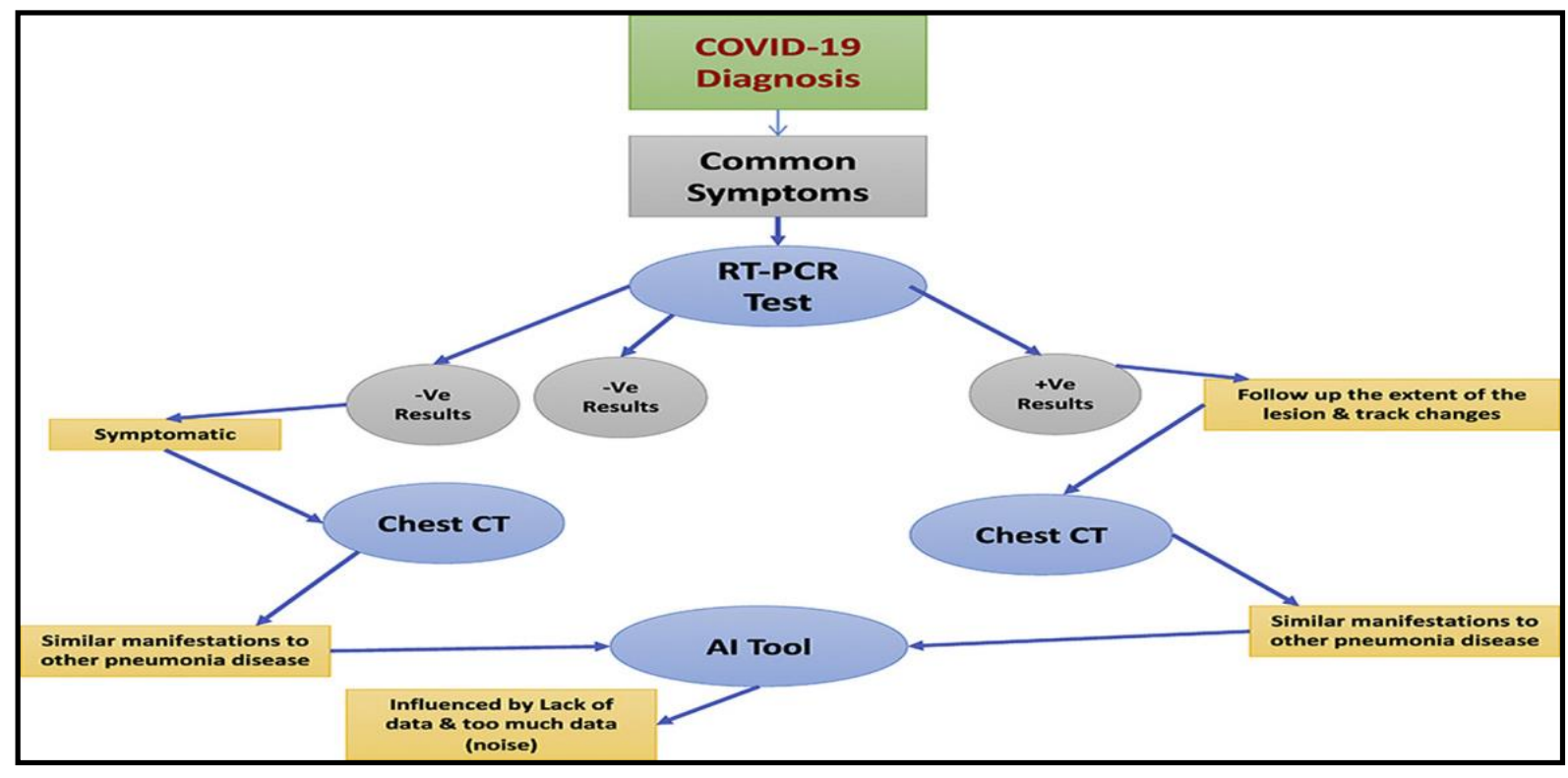

Figure 2. Diagnosis of Covid-19. ${ }^{17}$ 
enoxaparin. Moreover, high flow nasal oxygen therapy (HFNO) and Non-invasive ventilation are performed to deliver proper oxygen. Pulmonary epithelium inflammation is reduced by administering prednisone and prednisolone. ${ }^{25}$

Some traditional medicines are also approved as a beneficial remedy in treatment of COVID 19 - for example decoction combination of Ma Xing Gan Shi and Da Yuan Yin, Yin Giao San, Tu Ping Feng, Shuang Huang Lian etc. ${ }^{26}$

In treatment of rheumatoid arthritis, juvenile arthritis and giant cell arteritis Tocilizumab, a humanised $\operatorname{Ig} G$ 1 monoclonal antibody (directed against IL-6 receptor) is administered. Active tuberculosis and neutropenia are contraindicated for Tocilizumab. Tocilizumab also comes under consideration in treatment of COVID-19. ${ }^{27}$

\section{CONCLUSION}

COVID 19 today has become a notable threat to mankind. It has hampered the normal social workflow. Drugs and vaccines, however are not the only remedy of this pandemic. Moreover, due to some adverse effects, a number of drugs are avoided by patients. People, hence, should be aware of the Do's and Don'ts which they must apply in their everyday lifestyle such as sanitization, wearing masks, maintaining social distance or quarantine (if necessary). Consumption of a healthy balanced diet isvery important to build immunity against this severely transmissible disease. Prevention is always better than cure.

\section{REFERENCES}

1. Shereen MA, Khan S, Kazmi A, Bashir N, Siddique R. COVID-19 infection: origin, transmission, and characteristics of human coronaviruses. Journal of Advanced Research 2020;24:91-8. https://doi.org/10.1016/j.jare.2020.03.005

2.World Health Organization, Laboratory testing for coronavirus disease 2019 (COVID-19) in suspected human cases, World Health Organization, 2020.

3. Zhong NS, Zheng BJ, Li YM, Xie ZH, Chan KH, Li $\mathrm{PH}$, Tan SY Chang Q, Xie JP, et al. Epidemiology and cause of severe acute respiratory syndrome (SARS) in Guangdong, People's Republic of China, in February, 2003. Lancet. 2003;362(9393):1353-8.

4. Haagmans BL, Al Dhahiry SH, Reusken CB, Raj VS, Galiano M, Myers R, Godeke GJ, Jonges M, Farag E, Diab A, et al. Middle East respiratory syndrome coronavirus in dromedary camels: an outbreak investigation. Lancet Infect Dis. 2014;14(2):140-5.

5. Sohrabi C, Alsafi Z, O'Neill N, et al. World Health Organization declares global emergency: A review of the 2019 novel coronavirus (COVID-19) [published correction appears in Int J Surg. 2020 Apr 15;:]. Int J Surg. 2020;76:71-76. https://doi.org/10.1016/j.ijsu.2020.02.034.

6. Zhang T, Wu Q, Zhang Z. Probable Pangolin Origin of SARS-CoV-2 Associated with the COVID19 Outbreak [published correction appears in Curr Biol. $\quad 2020 \quad$ Apr 20;30(8):1578. https://doi.org/10.1016/j.cub.2020.03.022.

7. Organization WH: WHO Timeline-COVID-19. 2020. (Online Article). Available fomr: https://www.who.int/news-room/detail/27-04-2020who-timeline-covid-19. [Last Accessed on $15^{\text {th }}$

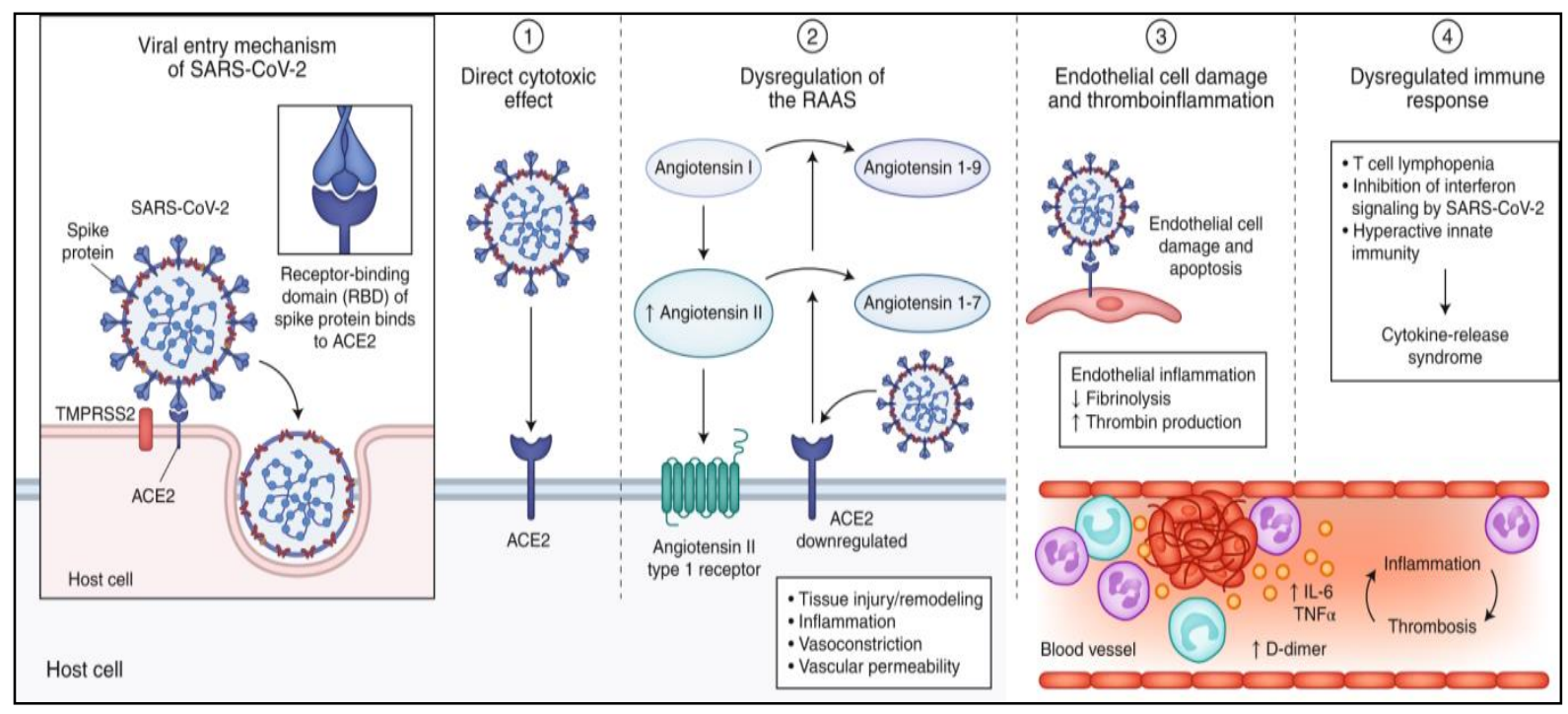

Figure 3. Pathophysiology of precipitation of Covid-19. ${ }^{21}$ 
December, 2021.]

8. Lu H, Stratton CW, Tang YW. Outbreak of pneumonia of unknown etiology in Wuhan, China: The mystery and the miracle. J Med Virol. 2020 Apr;92(4):401-402. https://doi.org/10.1002/jmv.25678. 9. Wang B, Li R, Lu Z, Huang Y. Does comorbidity increase the risk of patients with COVID-19: evidence from meta-analysis. Aging (Albany NY). 2020;12(7):6049-57.

https://doi.org/10.18632/aging.10300o.m

10. World Health Organization, "Coronavirus disease 2019 (COVID-19): Situation Report 61," March 2020, (Online Article) Available from: https://www.who.int/emergencies/diseases/novelcoronavirus-2019/ situation-reports. [Last Accessed on $15^{\text {th }}$ December, 2021]

11. Donnelly CA, Ghani AC, Leung GM, et al. Epidemiological determinants of spread of causal agent of severe acute respiratory syndrome in Hongkong. Lancet 2003;361:1761-6.

12. Jiang S, Du L, Shi Z. An emerging coronavirus causing pneumonia outbreak in Wuhan, China: calling for developing therapeutic and prophylactic strategies. Emerg Microbes Infect. 2020 Jan 31;9(1):275-277.

https://doi.org/10.108o/22221751.2020.1723441.

13. Hoffmann M, Kleine-Weber $\mathrm{H}$, Schroeder S, et al. SARS-CoV-2 cell entry depends on ACE2 and TMPRSS2 and is blocked by a clinically proven protease inhibitor. Cell 2020;181(2):271-80. https://doi.org/10.1016/j.cell.2020.02.052

14. Cascella M, Rajnik M, Cuomo A, et al., Features, evaluation and treatment coronavirus (COVID-19). Stat pearls [internet]. Treasure Island (FL): Stat Pearls Publishing, Jan 2020.

15. Sikachi R, Agrawal A. Whole body point of care ultrasound for COVID-19: a multisystem approach to a multi-system disease [published online ahead of print, 2020 Apr 16]. Anaesthesia. 2020;10.1111/anae.15087.

https://doi.org/10.1111/anae.15087

16. Azhar M, Phutela R, Ansari AH, et al. Rapid, fielddeployable nucleobase detection and identification using FnCas9. bioRxiv. 2020. https://doi.org/10.1101/2020.04.07. 028167

17. van de Veerdonk FL, Netea MG, van Deuren M, et al. Kallikrein-kinin blockade in patients with COVID-19 to prevent acute respiratory distress syndrome. Elife. Published online April 27, 2020.
18. Li W, Moore MJ, Vasilieva N, et al. Angiotensinconverting enzyme 2 is a functional receptor for the SARS coronavirus. Nature 2003;426:450-4.

19. Tang NL, Chan PK, Wong CK, et al. Early enhanced expression of interferon-inducible protein-1o (CXCL10) and other chemokines predicts adverse outcome in severe acute respiratory syndrome. Clin Chem. 2005;51:2333-40.

2o. Xu Z, Shi L, Wang Y, et al. Pathological findings of COVID-19 associated with acute respiratory distress syndrome. Lancet Respir Med. 2020;8:420-2. https://doi.org/10.1016/S2213-260o(20)30076-X

21. Ganyani T, Kremer C, Chen D, et al. Estimating the generation interval for coronavirus disease (COVID-19) based on symptom onset data, March 2020. Euro Surveill. 2020;25(17).

https://doi.org/10.2807/156o-7917.ES.2020.25.17.200

0257

22.Tchesnokov EP, Feng JY, Porter DP, et al. Mechanism of inhibition of Ebola virus RNAdependent RNA polymerase by remdesivir. Viruses 2019;11:326. https://doi.org/10.339o/v11040326

23. Bacharier LB, Guilbert TW, Mauger DT, et al., Early administration of azithromycin and prevention of severe lower respiratory tract illnesses in preschool children with a history of such illnesses: a randomized clinical trial. JAMA 2015;314:2034-44.

24 The Mint. Coronavirus vaccine update: Nod to human trial marks 'beginning of the end', says govt. (Online Article). Available https://www.livemint.com/news/india/coronavirusvaccine-nod-to-humantrial-marks-beginning-of-theend-says-govt-11593961927406.html [Last Accessed on $15^{\text {th }}$ December, 2021]

25. Clinical Management Protocol of COVID 19 Government of India, Ministry of Health and Family Welfare. Online PDF. Available from: https://www.mohfw.gov.in/pdf/ClinicalManagementP rotocolforCOVID-19.pdf [Last accessed on $2 \mathrm{O}^{\text {th }}$ June 2021)

26. Yang Y, Islam MS, Wang J, Li Y, Chen X. Traditional Chinese medicine in the treatment of patients infected with 2019-new coronavirus (SARS(oV-2): a review and perspective. International Journal of Biological Sciences 2020;16(10):1708-17. https://doi.org/10.7150/ijbs.45538

27. Buonaguro FM, Puzanov I, Ascierto PA. Anti-IL6R role in treatment of COVID-19related ARDS. J Transl Med. 2020;18:165. https://doi.org/10.1186/s12967-02002333-9 
Source of support: Nil, Conflict of interest: None declared

Cite this article as:

Bhattacharya A, Kundu R, Mahata LC, Kundagrami S, Dhara B, Mukherjee D. An Updated

Review on Epidemiology, Pathophysiology, Diagnosis and Treatment aspects of COVID-19

Infection. Int Healthc Res J. 2022;5(11):RV1-RV6. https://doi.org/10.26440/IHRJ/0511.02506

AUTHOR AFFILIATIONS: $\left({ }^{*}\right.$ Corresponding Author)

1. Assistant Professor, Department of Pharmacology, Calcutta Institute of Pharmaceutical Technology and Allied Health Science, Banitabla,

Uluberia, Howrah, 711316.

2. Department of Pharmaceutical Chemistry, Jadavpur University, Raja Subodh Chandra Mallick Rd, K P C Medical College and Hospital Campus, Jadavpur, Kolkata, West Bengal 700032.

3. Department of Pharmacology, Maulana Abul Kalam Azad University of Technology, Haringhata, Simhat Nadia, Pin-741249.

4. MBBS Student, North Bengal Medical College and Hospital, D-5 Quarter Sushruta Nagar, Dist, Darjeeling, West Bengal 734012.

5. Research Scholar, Department of Microbiology, St. Xavier's College [Autonomous], 30, Park St, Mullick Bazar, Park Street area, Kolkata, West

Bengal 700o16. (https://orcid.org/oooo-0002-5433-1994)

6. Clinical Intern, First Affiliated Hospital of Jinan University, 601 Huangpu Blvd W, Tianhe District, Guangzhou, Guangdong Province, China, 510632. (https://orcid.org/oooo-0001-7566-3843)

Contact Corresponding Author At: arghya.bh[at]gmail[dot]com 